\title{
21. Khoisan indigenous toponymic identity in South Africa
}

\author{
Peter E. Raper \\ University of the Free State, South Africa
}

\section{Introduction}

According to Webster's Dictionary (Gove 1961: 1151) 'indigenous' means 'not introduced directly or indirectly according to historical record or scientific analysis into a particular land or region or environment from the outside'. In terms of this definition the Bushmen (also called San) and Hottentots (also called Khoikhoi) are the true indigenous inhabitants of Southern Africa. These people, collectively known as the Khoisan, occupied vast areas of the African sub-continent, from the Zambezi Valley to the Cape (Lee and DeVore 1976: 5), for thousands of years (Mazel 1989: 12), and left behind a rich legacy of placenames. However, the Khoisan peoples were pre-literate, and their languages and the names they bestowed were unrecorded until the seventeenth century.

The African or 'Bantu' peoples migrated southwards in small groups or clans from the Great Lakes regions of Equatorial Africa (Krige 1975: 595-596), reaching the present KwaZulu-Natal between 1,500 and 2,000 years ago (Maggs 1989: 29; Mazel 1989: 13) and settling especially in the northern, eastern and south-eastern parts of the sub-continent.

From the late fifteenth century, Portuguese navigators sailed around the coast of Africa, and in 1652 the Dutch established a refreshment station at the Cape of Good Hope, leading to permanent settlement. They were followed by French, British, German and other peoples from Europe and Asia. Each wave of migrants adopted existing placenames, adapting them phonologically and later orthographically, translating some names fully or partially, and bestowing new names in their own language. Of course, when languages come into contact, mutual influence takes place, with sounds and words being 'borrowed' by each group of speakers.

In the course of time, and particularly during the past few centuries, many of the Khoikhoi and San cultures, and the languages spoken by these people, have to a large extent become extinct, and others are in the process of becoming so (Traill 1978: 147). Although many Khoikhoi placenames have survived, 
albeit in adapted form (Nienaber and Raper 1977; 1980), relatively few San placenames were considered to have survived (Pettman 1931: 13-17). Current research indicates, however, that a large number of San placenames have indeed survived, albeit adapted or transformed into the phonological and orthographic systems of Khoikhoi, African (Bantu) and European languages.

The present paper concentrates on placenames that are regarded as originating in European or African languages, but are in fact of Bushman or San origin.

From their placenames a great deal can be deduced about the identity of the San, and the things that make their placenames unique, e.g. the click sounds and various other aspects of their language. Some San words that are used as components of placenames reflect their environment, describing natural features and the character of their surroundings, and referring to animals and plants so essential to their survival, to the cosmetic and aesthetic use of natural pigments, and perhaps even to their deity. Many of these things have been recorded by anthropologists, linguists, Khoisanologists and others. But from a study of the vast corpus of placenames, many new facts may emerge, and above all, the original San placenames may be reconstructed by reversing the processes of adaptation, and recognised as the original indigenous toponyms of South Africa.

\section{Determining San influence}

The key to determining San influence on placenames hinges on the lexical meaning of the names, that meaning that first gave rise to the name, that was in the minds of the people who first gave and used the name (Sedgefield 1969: 1, 3). Nicolaisen (1976: 30) points out that the primary aim of onomastic research is to determine this meaning, so that 'something which is now opaque might be made transparent again. ... Without this maxim there would be no point in, and therefore no scholarly discipline of, the study of names'. This lexical meaning has, in the case of many San names and their adaptations into other languages, been preserved, through oral tradition and subsequent graphic recording. It is through comparing the preserved meanings with similar known San words that influence may be demonstrated.

The African (Bantu) languages and the Khoisan languages are not believed to be descended from a common ancestor and are thus not related to each other. When the term 'cognate' is used for words from these different languages, it is used in the sense of the definition given by Webster's Dictionary, namely 'related in a manner that involves borrowing rather than descent from or as well as descent from an ancestral language' (Gove 1961: 440). 
In order to appreciate the processes of adaptation that led to the present state of San names disguised as African-language names, note may be taken of some grammatical aspects of African and San languages.

\section{African languages}

African language names, like all nouns, consist of a stem and a prefix, and frequently also a suffix. The stem conveys the lexical meaning of the word, while the prefix indicates number (singular or plural), concord (which set of concordial agreement should be employed for agreement with other parts of speech in a sentence), and so forth (Koopman 2002: 267). Removing the prefix reveals the stem of a noun, and it is under this stem that the word is entered in dictionaries (Doke and Vilakazi 2005: xviii).

The Constitution of the Republic of South Africa (1996: 4) lists the official African languages as 'Sepedi, Sesotho, Setswana, siSwati, Tshivenda, Xitsonga, isiNdebele, isiXhosa and isiZulu', thus incorporating in the names of the languages the prefixes in each of the languages concerned. In academic and popular usage, however, non-mother tongue speakers generally employ the terms 'Zulu', 'Xhosa', 'Swazi' and so forth when referring to these languages and to the speakers concerned, terms that have also gained currency outside South Africa (Van Wyk 1993: 108). In the present paper the latter academic usage will be followed.

Several African languages, e.g. Sotho, Swazi, Xhosa and Zulu, have click sounds that are derived from the Khoisan languages. These are the dental click, written as $c$; the lateral click, written as $x$, and the palato-alveolar click, written as $q$. Whereas more than 70 per cent San words start with a click, comparatively few names in Nguni and Sotho languages do, and in some other languages not at all. The clicks originally occurring in San names and other words can thus be assumed to have been adapted to the African-language sound organically closest to the click.

In some African languages, e.g. Zulu, the juxtaposition of vowels is impermissible, and when words (and names) from other languages are taken over into such languages, the two vowels are contracted into one, or coalesced, or the first vowel is changed into the corresponding semi-vowel, or a consonant is inserted between the vowels, and so forth. Zulu, for example, does not permit the juxtaposition of certain consonants, for which reason Pretoria is adapted as ePitoli, Vryheid as eFilidi, etc. Also, African-language words must end in a vowel, except in the case of a syllabic $m$. 
African names frequently display the structure generic + specific, e.g. Thabazimbi, from intaba 'mountain', insimbi 'iron'; but some demonstrate the structure specific + generic, e.g. Nhlazatshe, from -luhlaza 'green', itshe 'stone'.

\section{San languages}

The San languages are characterised by click or suction consonants. These have been standardised in writing as:

(a) /, the dental or alveolar fricative click, pronounced by placing the tip of the tongue against the upper front teeth or alveolar ridge and withdrawing it rapidly;

(b) //, the lateral click, pronounced by placing the upper part of the tongue-tip against the alveolar ridge, with the tongue far back against the velum and the sides of the tongue against the upper side teeth, and withdrawing one side of the tongue from the upper teeth;

(c) !, the cerebral or palato-alveolar click, pronounced with the tongue-tip placed firmly on the point of division between palate and alveolar ridge, the back of the tongue placed against the velum and the sides of the tongue against the side upper gums, and releasing the tongue-tip sharply downwards, the resulting click resembling the sound of a cork being drawn from a bottle;

(d) $\neq$, the alveolar click, formerly called the palatal click, pronounced with the upper part of the tongue behind the tip pressed firmly against the gum-ridge behind the central upper teeth, the back of the tongue raised to touch the velum, and the sides of the tongue raised to complete the space of rarefaction between velum and alveolar ridge, and bringing the front of the tongue sharply down, the resulting click resembling the sound made by a child when tasting something sweet;

(e) the bilabial click, or lip click, usually represented in writing as a circle with a dot in the middle, but in this paper represented as $\Theta$; and

(f) the retroflex click, variously represented in writing as !! or /// (Bleek 1929: i; Bleek 1956: 640; Rust 1960: viii; Traill 1978: 137-138).

In all these clicks there is double closure: the back of the tongue is pressed against the velum and the sides of the tongue also touch the roof of the mouth, to create a space of rarefaction; as that is the same for all except the lip click, and is done quite unconsciously, I do not particularly name it in describing each click (Bleek 1929: 13).

The San clicks are not pronounced in isolation. Each of the clicks is pronounced with distinctive releases, accompaniments or effluxes, e.g. aspirated, ejected, 
fricative, glottal, nasal, preglottal, prevoiced, voiced, etc. The voiced efflux is indicated as in $/ g \tilde{a}$, the nasal efflux as in $/ n a$, the fricative efflux as in $/ x \tilde{a}$, the aspirated efflux as in / $h a$, and so forth. These effluxes yield between 20 and 85 distinct click segments for different languages, and some of them combine on a single click, 'yielding a system that is staggering in its phonetic complexity' (Traill 1978: 138).

In addition to the clicks, the San languages have many other complexities of pronunciation involving both consonants and vowels. 'The vowels of these languages are notable for their complex colourings, including plain, nasalised, breathy and pressed vowel colourings. These combine with each other to produce up to seven vowel colours for each of the five vowels.' (Traill 1978: 139). In this paper the symbol $\varepsilon$ is used to indicate a pressed vowel.

The San languages are tone languages. 'That means roughly that different words may have identical vowels and consonants but be distinguished by their tone alone.' (Traill 1978: 139). However, no attempt will be made in this paper to seek correspondences between San and African-language tones, since 'too many variables enter into the interpretation of the absolute pitch of the syllables of the words recorded on any particular day, and this makes it impossible to give such absolute pitch any accurate systematic phonetic or phonological interpretation.' (Doke and Vilakazi 2005: i), and 'Although tone has always been a useful tool when doubtful cases ... are to be distinguished from one another, it has very little value when it comes to place names, since tone can for reasons which are obvious, not be indicated on place names in gazetteers, atlases, etc.' (Louwrens 1994: 6). Furthermore, indigenous San placenames are ancient, and in their adaptation into African and other languages, the original tone structure may well also have undergone changes to fit the systems of the receiver languages. An investigation into the tones used by speakers of the receiver language today can reveal no more than the tones used in the adapted name or component, which may in some cases be a folk-etymological misinterpretation.

On the basis of the number and distribution of clicks, similarities in the roots of words, and other grammatical similarities, Bleek $(1929 ; 1956)$ divided the San languages into three groups, namely the Southern, Central and Northern Groups, and allocated the symbols S1, S2, S2a, N1, N1a, N2, N3, C1, Cla, etc. to them to facilitate reference to them. In the present investigation the name of the language referred to is given, together with the appropriate symbol in parentheses, e.g. /Xam (S1), Hadza (C3), Kung (N2). 


\section{Adapted San placenames}

As stated previously, the lexical meanings of many placenames have been preserved and recorded, and these meanings provide the key to ascertaining San origins of African-language placenames. Four onomastic techniques are employed in determining the San elements comprising the name:

(a) If a meaning has been recorded for the African-language name, that meaning is tested linguistically against recorded San words with the same meaning to determine possible semantic correspondence;

(b) where both an indigenous and European name occur for a feature, the possibility is examined of corresponding meanings that may indicate translation;

(c) topographic congruity, the occurrence of toponyms from different languages in close spatial proximity, may reveal transference and translation;

(d) topographical, geographical, geological, botanical or other evidence in the region or vicinity where the name occurs may give an indication of the meaning for the name, since these may have triggered the name or been the toponymic motive.

In all instances cognisance is taken of the possibility of folk etymological explanations.

\section{Given or recorded meanings}

In the following instances, the underlying San component(s) can be determined by comparison with the recorded meaning of the names.

The name Tshokwana is cognate with Hadza (C3) ts'okwana 'giraffe' (Bleek 1956: 219), the only phonological difference being the replacement of the San alveolar affricative plus glottal stop $t s^{\prime}$ by the Sotho lateral affricative $t s h$.

The river-name eMpunzini is said to be derived from the Zulu word impunzi, 'duiker' (Koopman 2002: 129). The component mpun of the word impunzi is cognate with Sesarwa (S5) Epyn 'duiker buck' (Bleek 1929: 35). The stem of this word is thought to be phunzi, 'common grey duiker buck' (Doke and Vilakazi 2005: 678), but the voiced bilabial consonant $m$ of the component im- is a replacement of the bilabial click $\Theta$, the cluster $\Theta p$ thus corresponding to the Zulu nasal bilabial consonant $m$ plus ejective bilabial $p$ in the cluster $m p$, while San $y$ in the word $\Theta p y n$, pronounced like $u$ in French ' $d u^{\prime}$ ', occurs as the Zulu high back vowel $u$. 
Madzivhanani is the name of a settlement, said to be of Venda origin and to mean 'where lakes are found', from madzivha 'lakes' (South African Geographical Names Council Agenda for 20 March 2002). Removal of the plural prefix mareveals the stem dzivha 'lake', cognate with Hie $(\mathrm{Cl}) d z$ žba 'lake, pool' (Bleek 1956: 33). The component nani is perhaps a Venda locative suffix.

uKhahlamba is the Zulu name for the Drakensberg Mountains (Koopman 2002: 155). This name is derived from the noun khahlamba (u(lu)kahlamba), meaning 'Broken mountain range' (Doke and Vilakazi 2005: 374). Other written forms of the name include Quahlamba, Quatlamba, Kwahlamba and Kwathlamba, all being attempts at rendering in writing the pronunciation of the name, indicating that the component Kha is a coalesced form of Qua, Kwa. This component is cognate with /Xam (S1) !kwa, Kung (N2) _!kwa 'to break' (Bleek 1929: 24). The underscore before the click denotes a low tone in the pronunciation of the word. The component hlamba is cognate with the /Xam (S1) word//khami 'chain of mountains' (Bleek 1956: 573). The hl of hlamba is the unvoiced alveolar lateral fricative corresponding to the unvoiced lateral fricative click $/ /$; the voiced bilabial consonant $m$ is perhaps a relic of a masculine singular ending later occurring as $b$.

Umtongata is the spelling given by Gardiner (1966 [1836]: 182) for the river name also encountered as Umtongate, Thongathi, uThongathi, Tongati, etc., and as Tongaat for the town. Stayt (1971) gives as one possibility the meaning of 'The Twisting River'. The component Um is the Zulu prefix; the component tonga is perhaps cognate with Kung (N2) tuy-a, tuy'a 'turn' (Bleek 1956: 241, 766), San $u$ variously heard as $u$ (back close) or $o$ (back half-close) (Bleek 1956: 246). The final component of the name, $-t a$ or $-t i$, is a fluvial generic term, ta perhaps cognate with /Xam (S1) / $k^{\prime} a$ 'river' (Bleek 1929: 70); ti perhaps with /Auni (S4) $\neq e i$ 'river' (Bleek 1956: 643), the unvoiced alveolar plosive consonant $t$ corresponding to the alveolar click / in the first case and with the alveolar plosive click $\neq$ in the second, in which the vowel cluster $e i$ is coalesced to the syllable peak $i$.

\section{Allonyms}

Many places, towns as well as natural features, have both African and European names. Of the former, some are demonstrably of San origin.

Mangaung, the Southern Sotho name for Bloemfontein, means 'place of cheetahs', Acinonyx jubatus, from mangau, the plural of the Class 6 noun of which the stem is ngau 'cheetah', cognate with the Hie (Cl) word khao 'cheetah' (Bleek 1956: 88 ), the Sotho voiced velar nasal compound $n g$ replacing the San aspirated velar 
consonant $k h$, the San back close vowel phoneme $u$ variously heard as back close $u$ or back half close $o$ (Bleek 1956: 246). The addition of the Sotho locative suffix -ng completes the adaptation to Mangaung (Louwrens 1994: 25).

Mašišing is the Sotho name for Lydenburg (Louwrens 1994: 9, 25), derived from the Class 6 noun mašiši 'tambookie grass' (Louwrens 1994: 10) plus the Sotho locative suffix -ng. The component šiši is cognate with the Auen (N1) word //e:si 'grass' (Bleek 1956: 519), the San lateral fricative click // replaced by the unvoiced fricative $\check{s}$ in the first syllable, the San unvoiced alveolar fricative $s$ by the unvoiced prepalatal fricative $\check{s}$ in the second syllable.

\section{Translations}

In some instances European allonyms seem to be translations of San placenames, or at least to have the same meaning.

The Dutch name Baviaans Rivier means 'baboon river'. The Xhosa name for this river is iNcwama (Skead 2001: 54-55), derived from ingcwam, a dialectal word for 'baboon' (Pahl in Skead 2001: 54). A /Auni (S4) word for 'baboon' is //nwaay (Bleek 1956: 623), cognate with the Xhosa root ngcwam, the San lateral click with voiced release $/ / n$ approximated by the Xhosa voiced form of the dental click preceded by the nasal, ngc, the San nasal $y$ often taking the form $m$ (Bleek 1956: 131). An alternative version of the Xhosa name is i-Quamma (Skead 2001: 54-55), the stem quam also cognate with //nwaay, the San lateral click //, also called the retroflex fricative click, 'made by spreading the tip of the tongue across the palate and drawing it gently backwards' (Bleek 1929: 13), correlating with the Xhosa palato-alveolar click $q$. It is therefore clear that the Dutch name Baviaans Rivier translates the San word //nwaay 'baboon', preserved in the adapted Xhosa name iNcwama and i-Quamma.

Cainsheneuj was recorded in 1777 by Colonel Robert Jacob Gordon as the Khoikhoi name for Grootvadersbos, and said to mean 'blind-fly forest', the component cainshe considered to be similar to Nama /geina, /gena 'blind-fly' (Nienaber and Raper 1977: 269), the component neuj 'forest' cognate with the element ney in the name Coerney 'narrow forest' (Raper 2004: 45). 'Grootvadersbos' literally means 'grandfather's bush'. The Batwa (S3) word for 'grandfather' is !xeinja (Bleek 1956: 490), which is similar in sound to cainshe, while the component neuj is like Kung (N2) $/ k^{-}{ }^{-}{ }^{\prime}$ 'bush' (Bleek 1956: 324, 701), the alveolar nasal $n$ approximating to the alveolar click /.

For the Cowie River that joins the Koonap at Adelaide, the Xhosa name iQoyi seems to be used consistently, i.e. with the palato-alveolar click Q. Earlier variants of the name include Kowie (1809), Qohi (1860), Kowie (1856)] and iQoyi 
(1915) (Skead 2001: 663-664). The Dutch name Kromme, meaning 'crooked', appears as an alternative to Kowie on Arrowsmith's map of 1835 (Skead 2001: 663-664). The winding course of the river was the reason for the name in Dutch, and may well also have been the toponymic trigger for the name in San. A Kung (N2) word for 'crooked, bent' is $-/ / k u b b i$ (Bleek 1956: 591), which is phonologically similar to Kowie and variants, the San click with velar efflux //k approximated by the velar plosive $K$, the San vowel phoneme $u$ variously heard as back close $u$ or as back half-close $o$ (Bleek 1956: 246); the bilabial vowel $b$ in the second syllable frequently changing into $w$ (Bleek 1956: 13). iQoyi is the Xhosa adaptation, the $i$ - being a locative prefix.

eMnqwala is the Xhosa name for the Waterkloof River that enters the Koonap at Adelaide (Skead 2001: 418). An older form of the name, recorded in 1851, is Gwala. Waterkloof is Afrikaans for 'water ravine', thus a translation of an older San name similar to Gwala of which eMnqala is the Xhosa adaptation. The component $e M$ is the Xhosa prefix; the component nqwa is cognate with /Xam (S1) !khwa:, !kwa: 'water' (Bleek 1956: 431,457), the voiced velar plosive consonant $G$ of the component $G w a$ and the nasal form of the palato-alveolar click $n q$ reflecting the ejective preceded by the palato-alveolar click, !k. The component (a)la of the name is perhaps cognate with San /ara 'kloof', 'ravine' (Bleek 1956: 729), the voiced alveolar consonant $l$ regularly replacing the voiced alveolar $r$. The component la may also be a fluvial generic term that occurs in river names such as Palala, Tugela, Pongola and so forth.

Mzinyathi, a Zulu river-name, is generally accepted as meaning 'home of the buffalo, buffalo village' (Botha 1977: 170), derived from umuzi 'home, village', and inyathi 'buffalo' (Doke and Vilakazi 2005: 895). However, Doke and Vilakazi inform us that this is the Zulu name for 'BloodRiver in North-west Natal' (Doke and Vilakazi 2005: 895). As frequently proves to be the case, Blood River is synonymous with an original San name of which Mzinyathi is a folk etymological adaptation. The component $(U) m$ is the Zulu prefix; the component $z$ in is cognate with Auen (N1) /in 'blood' (Bleek 1956: 292), the Zulu voiced alveolar fricative consonant $z$ corresponding to the San alveolar fricative click/, the nasals $n$ and $\eta$ often interchanging (Bleek 1956: 140). The component nyati, where the ny is perhaps a click replacement, is cognate with the San word ati 'water' (Bleek 1956: 769), although the $y$ may well be a glide between /in 'blood' and ati 'water'. Thus /inati $>$ zinyati $>(u M)$ zinyathi.

Mzinyathi is also the Zulu name for the stream known in Afrikaans as the Wakkerstroom, and for the town of the same name (Raper 2004: 399). In this case there is reason to suspect a San origin for the Zulu name. Wakkerstroom means 'lively stream', literally 'awake stream', wakker being Dutch and Afrikaans for 'to be awake'. A Batwa (S3) word for 'to be awake' is /he:nja (Bleek 1956: 287), which corresponds phonologically to the component zinya of the name (uM) 
zinyati, the voiced alveolar fricative $z$ approximating to the alveolar fricative click / (Bleek 1929: 13), the front close vowel $i$ interchanging with the front half-close vowel $e$ (Bleek 1956: 66). $u M$ is the Zulu prefix and $t i$ an adaptation of a fluvial generic term, e.g. /Auni (S4) $\neq e i$ 'river' (Bleek 1956: 643), or the //y !ke (S2) word / $k^{\prime}$ éi 'river' (Bleek 1929: 70), the alveolar click $\neq$ and / both approximating to the alveolar plosive consonant $t$, the vowel cluster ei coalesced to $i$ in order to obviate the juxtaposition of two vowels that would violate the Zulu canon.

Tlokwe, the Tswana or Northern Sotho name for the Mooi River, is a name proposed as a replacement for the town name Potchefstroom. The component kwe is cognate with the Hie (C1) word kwe 'river' (Bleek 1929: 70), suggesting the possibility of the component Tlo being an adaptation of a San word meaning 'pretty', of which Mooi is the Afrikaans translation. Louwrens (1994: 7) points out that the eastern Sotho dialects are renowned for displaying dental sounds (e.g. $t h$ and $t$ ) for lateral sounds (e.g. $h l, t l, t l h)$ in the standard language. The component Tlo may thus be cognate with the Naron (C2) word tõe, tõ $i$ 'pretty' (Bleek 1956: 207), Tlokwe thus meaning 'pretty river', Afrikaans Mooirivier.

uThukela is said to be the correct Zulu spelling for the name of the Tugela River. This name has been explained as 'the frightening one, the fearsome one' (Botha 1977: 206), derived from the ideophone thuka 'of fright, startling; of sudden fear' (Doke and Vilakazi 2005: 804). The earliest recorded form of the name was Tugala (Gardiner 1966 [1836]: 30, 69, 312, 372; Owen 1836: (Cory 1926: 271)), thus with an $a$ after the velar $g$. An early name for the Tugela was Fisher's River (Botha 1977: 207; Hermann 1936: 56; Skead 1973: 230). The river also bore the Portuguese name Rio da Pescaria, 'river of fishers', and the headland at its mouth now the Tugela Bluff bore the Portuguese name of Ponta da Pescaria, recorded as such by Perestrelo in 1675 (Da Costa 1939: 85). The name Tugela, or Tugala, is thought to have the same meaning as Rio da Pescaria and Fishers River. The stem of the name has been recorded as Tu, To, 'Tu, Toe, etc., cognate with //Khau (S2b) tho:e: 'fish' (Bleek 1956: 200). The second component of the name, recorded as ga, ge, gee and ke, may be cognate with /Xam (S1)!k'e, !'e, !ke, !e 'people, men' (Bleek 1929: 56; 1956: 373), and the final component, la, a fluvial generic as in Pongola, Palala, etc.

The town name Lephalale, taken from that of the Palala River, is said to be derived from the Tswana and Pedi verb -falala 'overflow' (Louwrens 1994: 23). However, Louwrens's statement that 'The resulting deverbative can ... not be translated in a sensible way' (Louwrens 1994: 23), and the seemingly anomalous spellings of the verb falala and its development from verb to noun as (le)phalala, prompt the suspicion that the explanation of the name given above may have been suggested by the similarity in sound of the river-name to the verb falala. A variant name for the Palala River is Rhooebok R. (Skead 1973: 175). Rhooebok is 
a misspelling of 'rooibok', Afrikaans for 'redbuck, impala antelope' (Kritzinger 1954: 403). The component Le- in the variant Lephalala is the Sotho class 5 prefix (Louwrens 1994: 22), the stem of the name being phala, pala. As is frequently the case when a feature has both a European and an indigenous name, they have the same meaning, the root pala being cognate with the Hukwe (C2b) word pala 'rooibok' (Bleek 1956: 156). The suffix -la of the name is thought to be an adapted generic term meaning 'river' that also occurs in river-names like Tugela, Pongola, and the like.

\section{Topographical congruence}

In a number of cases topographical congruity provides the explanation for the origin or meaning of a name. In other words, where given meanings are suspect or unsatisfactory, or no meaning can be found, the name of a feature close to the one in question, part of the same toponymic configuration, may provide the key in the form of a translation.

eAdo, also recorded as eNqado, is the Xhosa form of Addo, the name of the famous elephant park. Earlier recorded Khoisan forms include Kadouw (1820), Ado (1832), K'adouw (1833) and Kadouw (1843), in each case written with one intervocalic $-d-$, as opposed to the two in the form recorded by Thompson 1827 as Addo, by Hall (map 1856) in the name Kaddobush, etc. Nienaber and Raper (1977: 170) suggested the meaning of 'Euphorbia pass', from Khoikhoi !Ga 'poison'. Arguments against this explanation are that the Khoikhoi word for 'poison' is consistently written with a $g$, while the placename has never been recorded with a $g$; and that 'Euphorbia' and 'poison' are not synonymous. Skead (pers. comm. in letter 22 June 2005) states that the Addo Valley consists of flat ground between low, widely-separated scarps, and that Soutkloof is the only kloof or pass in the valley. This pass carries the main roads through the otherwise steep escarpment, and would also have been the route traversed by wagoners in olden times. Besides correlating well with Addo topographically, the linguistic congruence between the two names is convincing. The name Soutkloof is Dutch (and Afrikaans) for 'salt ravine'. A Khoisan word for 'salt' is kxa (1689) (Nienaber 1963: 464), cognate with Sesarwa (S5) !xa:ne 'salt' (Bleek 1929: 71). The unvoiced velar fricative $x$ being represented in the written records by the apostrophe ' shows kxa to correspond to the element $K^{\prime} a$ - of $K^{\prime}$ adouw, develarised as Addo, while for 'ravine' or 'kloof' the word dau was recorded in 1689 (Nienaber 1963: 342), which correlates with the element do of Addo (Nienaber and Raper 1977: 169). Soutkloof is a translation of Addo, 'salt ravine' or 'salt pass'. 
The name Cango, also encountered in the form Kango, from which the famous Cango Caves take their name, is said to mean 'wet mountain'. The component $\mathrm{Ka}(n)$ is cognate with /Xam (S1)/ka: $\varepsilon, / / k a$ : 'to be wet' (Bleek 1956: 294), the component (n)go with /Auni (S4) !gou, !kau, Hie (Cl) !gau 'mountain, hill' (Bleek 1956: 387). One wonders whether a more directly descriptive aspect could have led to the name of this mountain. The region known as the Kango or Cango is on the southern slopes of the Swartberg, and probably took its name from the mountain itself. Swartberg is Afrikaans for 'black mountain' (Raper 2004: 360). A San word for 'black' is / $k^{\prime \prime} a: a$, (Bleek 1956: 698), which is phonologically compatible with the component $K a(n)$ of the name Kango, the component ( $n$ )go with /Auni (S4) !gou, !kau, Hie (Cl) !gau 'mountain, hill' (Bleek 1956: 387), as shown above, so that Swartberg is perhaps a translation of the San name, or at least synonymous.

eNtabazwe is the Zulu name for Harrismith, said to be derived from intaba 'mountain' + izwe 'country', and to refer to mountainous country (Koopman 2002: 124). Considering such an explanation to lack distinguishing valence, an alternative explanation, based on topographic contiguity, was sought. To the east and north-east of Harrismith is a large mountain with the Afrikaans name Platberg (Walton 1984: 151), meaning 'flat mountain'. The Zulu name of that mountain is eNtabazwe. It is believed that Harrismith took its Zulu name from the mountain, and that eNtabazwe is an adaptation of a San name meaning 'flat mountain'. The component ntaba is cognate with Naron (C2) / ka:ba 'flat' (Bleek 1929: 39), the alveolar plosive consonant after homorganic nasal $n t$ of $n t a b a$ approximating to the San alveolar click with ejected efflux / $k$ of $/ k a$ :ba; the component zwe cognate with Batwa (S3) zhe [3e] 'stone'.

iKhalana, also encountered as Kalana, is the Xhosa name for the Little Thomas River (Skead 2001: 221). Pahl (1982 in Skead 2001: 221) derives the name from the word ikhalana, 'small aloes, e.g. Aloe tenuior'. The presence of small aloes along the river seems to have been the reason for its name in Xhosa, and may well also have been the reason for its name in San. A Naron (C2) word for 'aloe' is $\neq$ umme (Bleek 1956: 676). Recognising that the San alveolar or dental click $\neq$ is frequently replaced in the adaptation process by the dental or alveolar consonant $t$, and considering the variability in pronunciation of $u$ and $o$ (Bleek 1956: 246), it is possible to see that the San word $\neq u m m e$ 'aloe' has been interpreted folk etymologically as Thomas.

Modimolle is the Northern Sotho name that replaced the town name Nylstroom. Modimolle is primarily the name for Kranskop, a hill to the north-east of the town. The name 'Kranskop' means 'cliff hillock', from Afrikaans krans 'cliff', kop 'hillock'. The component Mo- of the name Modimolle is the Sotho Class 1 prefix (Louwrens 1994: 17), the component dimo cognate with the Hie (C1) word njimo 'high' (Bleek 1956: 147). The component olle is an adaptation of the 
Hadza (C3) word //ulle 'hill' (Bleek 1956: 628), the lateral click dropped in the adaptation process, the vowels $o$ and $u$ variable (Bleek 1956: 246). Modimolle is thus an adaptation of the San name meaning 'high hill', descriptive of the feature later known as Kranskop.

Kurrichane was the name of the early nineteenth-century capital of the Bahurutshe, situated north-east of Zeerust, on the slopes of the present Enselsberg. There is a topographic correlation between Kurrichane and the pass where it was situated, Witpoortjie, formerly bearing the Dutch name Wit Poortje. The latter name means 'little white pass', Wit meaning 'white', poort being defined as 'gate, gateway; narrow pass between precipitous mountains'. A linguistic correlation between the names Kurrichane and Witpoortjie is demonstrable. The component Kurri of the name Kurrichane is cognate with the /Nu//en (S6) word !kari 'white' (Bleek 1929: 91), while the component chane is cognate with the /Auni (S4) word !ane 'path' (Bleek 1929: 64). In the former case the alveo-palatal click ! has not been retained in the Tswana adaptation; in the latter the San palato-alveolar click! has been replaced by the sound represented as $c h$.

\section{0. 'Corrections'}

Attempts are sometimes made to correct placenames, to bring them in line with the most recent orthographic rules, or to give 'meaning' to names the meanings of which are unknown or uncertain.

For example, Pudimoe, the name of a town, was changed to Pudumong, said to mean 'place of the black wildebeest', from Tswana pudomô 'black wildebeest' (Connochaetes gnou) plus the locative suffix ng (Raper 2004: 313). It seems, however, that Pudimoe was the correct rendering of an original San name meaning 'goat spring', pudi being Hie (Cl) for 'goat' (Bleek 1929: 43), moe cognate with Hie (C1) moe, (Bleek 1956: 137), Khoikhoi mũ, 'eye, spring, fountain' (Nienaber 1963: 408). Pudumong thus seems to be based on an attempt at seeking a Tswana explanation for the San name Pudimoe, with the addition of the Tswana locative suffix -ng, and the 'correction' seems to be unjustified.

In an attempt at 'correcting' the name Kurrichane, and in the belief that early recorders were incapable of correctly hearing and interpreting Tswana words and names, Boeyens and Cole (1995: 21; 2005: 32) state that Kurrichane, the name of the early nineteenth-century capital of the Bahurutshe, is a corruption of Kaditshwêne, 'most probably derived by ellipsis from the idiomatic expression "Ga se ka ditshwêne" (What an incredible number of baboons!)' However, the form Kaditshwêne first appeared in an article published in 1937 (Boeyens and Cole 1995: 11), and could thus not have been the original form of the name, 
being coined one hundred and seventeen years later after Kurrichane was recorded. Kaditshwêne therefore seems to be an attempt at rendering in modern Tswana orthography the San name adapted as Bahurutshe Kurrichane.

At the 14th Congress of the Names Society of Southern Africa, held at the Ithala Game Reserve in November 2006, Professor Noleen Turner announced that Zulu placenames were systematically being corrected to bring them in line with the latest Zulu orthography. At the time I appealed for the information on the previous renderings of the names to be preserved in view of current research indicting that many Zulu placenames are in fact adaptations of Bushman names, and the more they are 'corrected', the more the indigenous toponymic identity of the San is obliterated.

\section{Conclusion}

A large number of placenames from San languages have been adapted into Sotho, Swazi, Tswana, Venda, Xhosa, Zulu and other African languages. In the process the placenames bestowed by the San have been obliterated or at least rendered unrecognisable, and the toponymic indigenous identity of the San has been disguised and obliterated. The San languages are not official, and there are few officially approved San placenames.

In terms of the South African Geographical Names Council Act (Act No. 118 of 2002), one of the functions of this Council is the transformation and standardization of geographical names'. By 'transformation' is meant replacing names of 'European' origin with one from African languages. Thus Ellisras was changed to Lephalale, Nylstroom to Modimolle, Messina to Musina, Pietersburg to Polokwane, and so forth (South African Geographical Names Council Agenda 20 March 2002). Several of these names, however, attest to a San identity.

The Constitution of the Republic of South Africa (1996: 4) states that, 'Recognising the historically diminished use and status of the indigenous languages of our people, the State must take practical and positive measures to elevate the status and advance the use of these languages', and that the 'Pan South African Language Board must promote and create conditions for the development and use of ... the Khoi, Nama and San languages'.

In accordance with the stipulations of the Constitution, and in pursuance of United Nations resolutions urging the recognition of the national identity of indigenous minority groups, it may be advisable to give greater recognition to San origins of placenames. 
The present paper is based on a research project that is still in its infancy. New findings have thrown light on the relationship between prefixes and word stems in the African languages, on that between generic terms and suffixes, on the morphological structure of placenames, and so forth. However, the full ramifications of this research can only be guessed at. Indications are that discoveries will be made on the relationship between the various San languages and their classification, on the influence of San languages on African language dialects, and so forth, as well as on aspects relating to the cultural and social heritage of the San.

\section{References}

Andrews, T.E. 1991, Indigenous Place Names Past and Present: Natal, Zululand, Swaziland, Private Publication, Pretoria.

Bleek, D.F. 1929, Comparative Vocabularies of Bushman Languages, University Press, Cambridge.

— 1956, A Bushman Dictionary, American Oriental Society, New Haven, Conn.

Bleek, W.H.I. 1862, A Comparative Grammar of South African Languages, Trübner \& Co., London.

Bornman, H. 1993, A Dictionary of siSwati Place Names, Country Life, Nelspruit, South Africa.

Botha, T.J.R. 1977, Watername in Natal, Raad vir Geesteswetenskaplike Navorsing, Pretoria.

Boeyens, J.C.A. and D.T. Cole, 1995, 'Kaditshwene: what's in a name?', Nomina Africana 9(1): 1-40.

- 2005, 'Whence Tswenyane? The etymology of an age-old Tswana place name in the Marico', Nomina Africana 19(1): 31-65.

Constitution of the Republic of South Africa, 1996, Government Printer, Pretoria.

Cory, Sir G.E. (ed.) 1926, The Diary of the Rev. Francis Owen, M.A., Missionary with Dingaan in 1837-38, Van Riebeeck Society, Cape Town.

Da Costa, A. F. (ed.) 1939, Roteiro of the South and South-East Africa, from the Cape of Good Hope to Cape Corrientes (1576) by Manuel de Mesquita Perestrelo. Republica Portuguesa Ministério das Colónias, Lisboã. 
Indigenous and Minority Placenames

Doke, C.M. and B.W. Vilakazi (comp.) 2005, Zulu-English Dictionary, Witwatersrand University Press, Johannesburg.

Duminy, A. and B. Guest (eds) 1989, Natal and Zululand from Earliest Times to 1910: A New History, University of Natal Press and Shuter and Shooter, Pietermaritzburg.

Gardiner, A.F. 1966 [1836], Narrative of a Journey to the Zoolu Country in South Africa, [William Crofts, London], Facsimile reprint, Struik, Cape Town.

Gove, P. B. (ed.) 1961, Webster's Third New International Dictionary of the English Language Unabridged, G. Bell and Sons, London; G. \& C. Merriam, Springfield, Mass.

Hattingh, P.S., N. Kadmon, P.E. Raper, and I. Booysen (eds) 1993, United Nations Group of Experts on Geographical Names Training Course in Toponymy for Southern Africa, University of Pretoria, Pretoria.

Hermann, L. (ed.) 1936, 1937, Travels and Adventures in Eastern Africa by Nathaniel Isaacs, 2 volumes, Van Riebeeck Society, Cape Town.

Jenkins, T. and P. V. Tobias 1977, 'Nomenclature of population groups in Southern Africa', African Studies 36: 49-55.

Koopman, A. 1983, 'Zulu place-names in the Drakensberg', in GS Nienaber - ' $n$ Huldeblyk, A.J.L. Sinclair (ed.), University of the Western Cape, Bellville: 297-306.

— 2002, Zulu Names, University of Natal Press, Pietermaritzburg.

Krige, E. J. 1975, 'Zulu', in Standard Encyclopaedia of Southern Africa, D.J. Potgieter et al. (eds), vol. 11, Nasou, Cape Town: 595-601.

Kritzinger, M.S.B. (ed.) 1954, Groot Woordeboek Afrikaans-Engels, EngelsAfrikaans, Van Schaik, Pretoria.

Lee, R. B. and I. DeVore (eds) 1976, Kalahari Hunter-Gatherers: Studies of the !Kung San and their Neighbours, Harvard University Press, Cambridge, Mass.

Lubbe, H.J. (ed.) 2007, Kritiese Aspekte van Naamsverandering/ Critical Aspects of Name Changing, Acta Academica Supplementum 2007(1).

Louwrens, L.J. 1994, 'A linguistic analysis of Sotho geographical names', Nomina Africana 8(1): 1-42. 
Maggs, T. 1989, 'The Iron Age farming communities', in Natal and Zululand from Earliest Times to 1910: A New History, Andrew Duminy and Bill Guest (eds), University of Natal Press and Shuter and Shooter, Pietermaritzburg: 28-48.

Mawer, A and F.M. Stenton (eds) 1969, Introduction to the Survey of English Place-names, University Press, Cambridge.

Mazel, A. 1989, 'The Stone Age peoples of Natal', in Natal and Zululand from Earliest Times to 1910: A New History, Andrew Duminy and Bill Guest (eds), University of Natal Press and Shuter and Shooter, Pietermaritzburg: 1-27.

Nicolaisen, W.F.H. 1976, Scottish Place Names, BJ Batsford, London.

Nienaber, G.S. 1963, Hottentots, Van Schaik, Pretoria.

Nienaber, G.S. and P.E. Raper 1977, 1980, Toponymica Hottentotica, 3 volumes, Raad vir Geesteswetenskaplike Navorsing, Pretoria.

Pahl, H. 2001, Correspondence incorporated in Skead, C.J. 2001, Pilot Gazetteer of Xhosa Placenames, Port Elizabeth Museum, Port Elizabeth.

Perestrelo, M. de Mesquita 1576, Roteiro of the South and South-East Africa, from the Cape of Good Hope to Cape Corrientes (1576), annotated by A. Fontoura da Costa, Ministério das Colónias, Lisboa, 1939.

Pettman, C. 1931, South African Place Names Past and Present, Daily Representative, Queenstown.

Potgieter, D.J. (ed) 1975, Standard Encyclopaedia of Southern Africa, Nasou, Cape Town.

Raper, Peter E. 2004, New Dictionary of South African Place Names, Jonathan Ball, Johannesburg and Cape Town.

- 2007, 'Transformation of place-names in South Africa', in Kritiese Aspekte van Naamsverandering/ Critical Aspects of Name Changing, H.J. Lubbe (ed.), Acta Academica Supplementum 1: 110-138.

Rust, Fr 1960, Deutsch-Nama Wörterbuch, Rheinischen Mission in Südwestafrika, Windhoek.

Sedgefield, W.J. 1969, 'Methods of place-name study', in Introduction to the Survey of English Place-names, A. Mawer and F.M. Stenton (eds), University Press, Cambridge: 1-14.

Skead, C.J. 1973, Zoo-Historical Gazetteer, Cape Provincial Museums, Grahamstown. 
Indigenous and Minority Placenames

— 2001, Pilot Gazetteer of Xhosa Placenames, Port Elizabeth Museum, Port Elizabeth.

Stayt, D. 1971, Where on Earth? Place-names of Natal and Zululand, The Daily News, Durban.

Thompson, G. 1927, Travels and Adventures in Southern Africa, Henry Colburn, London.

Tobias, P.V. (ed.) 1978, The Bushmen, Human and Rousseau, Cape Town.

Traill, A. 1978, 'The languages of the Bushmen', in The Bushmen, P.V. Tobias (ed.), Human and Rousseau, Cape Town: 137-147.

United States Board on Geographic Names 1992, Gazetteer of South Africa, $2^{\text {nd }}$ ed., 4 volumes, Defense Mapping Agency, Washington, DC.

Van Wyk, E.B. 1993, 'The standardization of African languages', in United Nations Group of Experts on Geographical Names Training Course in Toponymy for Southern Africa, P.S. Hattingh, N. Kadmon, P.E. Raper, and I. Booysen (eds), University of Pretoria, Pretoria: 105-115.

Walton, C. (ed) 1984, Reader's Digest Atlas of Southern Africa, Reader's Digest Association, Cape Town. 
This text taken from Indigenous and Minority Placenames: Australian and International Perspectives, Edited by Ian D. Clark, Luise Hercus and Laura Kostanski, published 2014 by ANU Press, The Australian National University, Canberra, Australia. 